\title{
Kinetic analysis of aptazyme-regulated gene expression in a cell-free translation system: Modeling of ligand-dependent and -independent expression
}

\author{
SHUNGO KOBORI, ${ }^{1}$ NORIKAZU ICHIHASHI, ${ }^{1,2}$ YASUAKI KAZUTA, ${ }^{2}$ TOMOAKI MATSUURA,,${ }^{1,2,3}$ \\ and TETSUYA YOMO ${ }^{1,2,4,5}$ \\ ${ }^{1}$ Graduate School of Information Science and Technology, Osaka University, Osaka 565-0871, Japan \\ ${ }^{2}$ Exploratory Research for Advanced Technology, Japan Science and Technology Agency, Osaka 565-0871, Japan \\ ${ }^{3}$ Graduate School of Engineering, Osaka University, Osaka 565-0871, Japan \\ ${ }^{4}$ Graduate School of Frontier Biosciences, Osaka University, Osaka 565-0871, Japan
}

\begin{abstract}
Aptazymes are useful as RNA-based switches of gene expression responsive to several types of compounds. One of the most important properties of the switching ability is the signal/noise $(\mathrm{S} / \mathrm{N})$ ratio, i.e., the ratio of gene expression in the presence of ligand to that in the absence of ligand. The present study was performed to gain a quantitative understanding of how the aptazyme $\mathrm{S} / \mathrm{N}$ ratio is determined by factors involved in gene expression, such as transcription, RNA self-cleavage, RNA degradation, protein translation, and their ligand dependencies. We performed switching of gene expression using two onswitch aptazymes with different properties in a cell-free translation system, and constructed a kinetic model that quantitatively describes the dynamics of RNA and protein species involved in switching. Both theoretical and experimental analyses consistently demonstrated that factors determining both the absolute value and the dynamics of the $\mathrm{S} / \mathrm{N}$ ratio are highly dependent on the routes of translation in the absence of ligand: translation from the ligand-independently cleaved RNA or leaky translation from the noncleaved RNA. The model obtained here is useful to assess the factors that restrict the $\mathrm{S} / \mathrm{N}$ ratio and to improve aptazymes more efficiently.
\end{abstract}

Keywords: aptazyme; allosteric ribozyme; cell-free translation system; kinetic model; S/N ratio

\section{INTRODUCTION}

Riboswitches are RNA-based regulators of gene expression that bind to a specific ligand and alter downstream or upstream gene expression through a conformational change. Many riboswitches have been found in nature, mainly in prokaryotes, and play important roles in the regulation of metabolism (Winkler and Breaker 2005). Artificial RNAs with similar switching function have been constructed by combining two modules: an aptamer module, which binds to a specific compound (ligand), and a regulator module, which changes its conformation depending on ligand binding to regulate gene expression (Davidson and Ellington 2005; Isaacs et al. 2006; Suess and Weigand 2008). Such riboregulators are classified into several types based on the

\footnotetext{
${ }^{5}$ Corresponding author

E-mail yomo@ist.osaka-u.ac.jp

Article published online ahead of print. Article and publication date are at http://www.rnajournal.org/cgi/doi/10.1261/rna.032748.112.
}

regulation mechanisms, such as those that directly induce or repress gene expression downstream in cis (Suess et al. 2003, 2004; Desai and Gallivan 2004; Lynch et al. 2007; Sharma et al. 2008; Weigand et al. 2008; Ogawa 2011), those that alter the degree of hybridization resulting in induction or repression of genes in trans (Bayer and Smolke 2005), and those that induce ribozyme activity resulting in alteration of gene expression (Robertson and Ellington 1999; Soukup and Breaker 1999b, 2000; Piganeau et al. 2000; Thompson et al. 2002; Yen et al. 2004; Wieland and Hartig 2008; Wieland et al. 2009). These latter artificial regulators are called allosteric ribozymes, or aptazymes. To date, several aptazymes have been constructed using hammerhead ribozyme for various types of ligands, including ATP (Tang and Breaker 1997), FMN (Araki et al. 1998; Soukup and Breaker 1999a), theophylline (Soukup and Breaker 1999a; Wieland and Hartig 2008), cyclic nucleotide monophosphates (Koizumi et al. 1999), and thiamine pyrophosphate (TPP) (Wieland et al. 2009). These aptazymes have been used for a wide range of applications, such as 
artificial gene regulation in vivo (Kumar et al. 2009; Carothers et al. 2011) and as biosensors in vitro (Breaker 2002; Hesselberth et al. 2003; Ogawa and Maeda 2007).

One of the most important properties of aptazymes for gene switching is the signal/noise $(\mathrm{S} / \mathrm{N})$ ratio, i.e., the ratio of gene expression in the presence of the ligand (signal) to that in the absence of the ligand (noise). However, which aptazyme parameters determine the $\mathrm{S} / \mathrm{N}$ ratio is not quantitatively understood. In previous studies, ligand-dependent ribozyme activities were often analyzed as parameters of aptazymes relevant to the $\mathrm{S} / \mathrm{N}$ ratio (Thompson et al. 2002; Wieland et al. 2009). In the cell, however, various reactions, such as transcription, translation, and degradation can also affect the $\mathrm{S} / \mathrm{N}$ ratio to different extents. Therefore, a better understanding of the factors that determine the $\mathrm{S} / \mathrm{N}$ ratio among these reactions is required to design an aptazyme with better switching properties.

Cell-free translation systems are useful platforms to analyze aptazyme function in the context of various reactions involved in gene expression, such as transcription, translation, and RNA degradation. Such systems allow strict control of ligand concentration and precise measurement of the RNA and protein species involved in the switching reaction, all of which are difficult in the cell (Karzbrun et al. 2011). The information obtained in vitro can be used to design and understand the function of aptazymes in vivo. Previously, Ogawa and Maeda (2007) reported that some aptazymes work in a cell-free translation system. Here, we examined the kinetic mechanism determining the $\mathrm{S} / \mathrm{N}$ ratio of aptazymes in a cell-free translation system.

Several groups have reported aptazyme kinetic models (Chen and Ellington 2009; Carothers et al. 2011). Here, we constructed a modified version of the model of Chen and Ellington that includes two types of background gene expression in the absence of ligand. Simulation using the model quantitatively described the dynamics of the RNA and protein species involved in gene switching by the aptazyme, as well as its $\mathrm{S} / \mathrm{N}$ ratio. The validity of this model was further confirmed using a mutant aptazyme with different properties. Moreover, based on the kinetic model, we formulated the $\mathrm{S} / \mathrm{N}$ ratio as a function of the aptazyme parameters.

\section{RESULTS}

\section{Kinetic model}

Switching of gene expression by aptazymes is achieved by various types of reactions, including transcription of RNA, ligand binding, self-cleavage by ribozyme activity, translation of protein, and degradation of RNA. To understand the determinants of the $\mathrm{S} / \mathrm{N}$ ratio in the context of these reactions, we first attempted to construct a kinetic model that describes the dynamics of these reactions quantitatively. Here, we focused on on-switch aptazymes developed by Wieland and coworkers (Wieland and Hartig 2008; Wieland et al. 2009). In the absence of the ligand, this type of aptazyme conceals the SD sequence of the downstream gene by hybridization with the antisense region, thus repressing translation of the gene product (Fig. 1A). Once the ligand binds, the aptazyme induces its self-cleavage, resulting in exposure of the SD sequence and translation of the gene product.

We modified the previous aptazyme kinetic model of Chen and Ellington (2009) (Fig. 1B). Briefly, we introduced
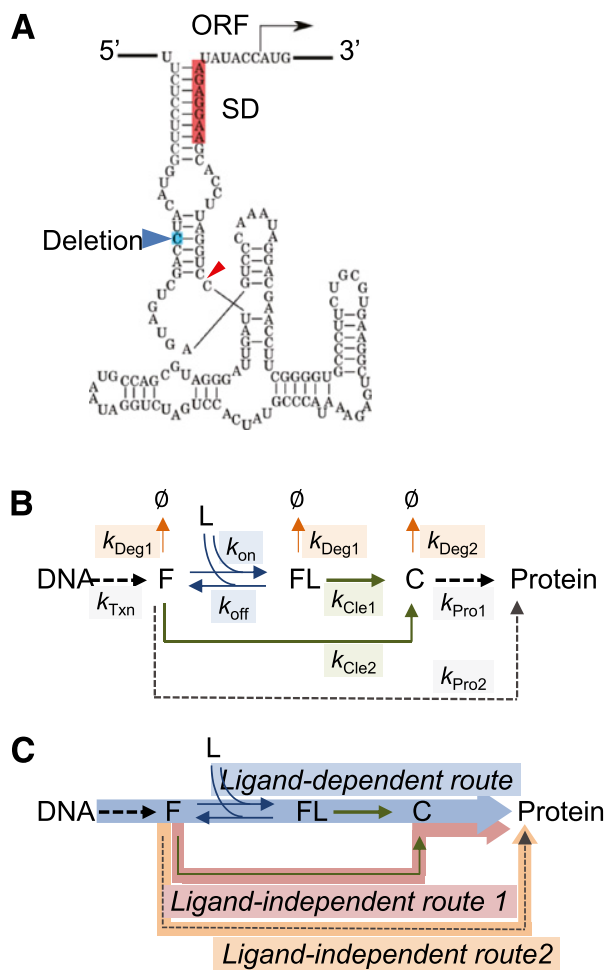

FIGURE 1. (A) TPP-responsive on-switch aptazyme developed by Wieland and coworkers. (Red highlight) The SD sequence; (red arrowhead) the self-cleavage site; (blue highlight) the deleted base of the mutant DelC. (B) Scheme of the kinetic model for switching of gene expression by an aptazyme. (DNA) DNA encoding the aptazyme and protein gene; (F) free full-length RNA; (L) ligand; (FL) ligandbound full-length RNA; $(\mathrm{C})$ cleaved RNA; (Protein) protein; $\left(k_{\mathrm{Txn}}\right)$ transcription rate constant; $\left(k_{\mathrm{on}}\right)$ association rate constant with ligand; $\left(k_{\text {off }}\right)$ dissociation constant with ligand; $\left(k_{\text {Cle1 } 1}\right)$ ligand-dependent self-cleavage rate constant; $\left(k_{\mathrm{Cle} 2}\right)$ ligand-independent selfcleavage rate constant; $\left(k_{\mathrm{Prol}}\right)$ translation rate constant from the cleaved RNA; $\left(k_{\mathrm{Pro} 2}\right)$ leaky translation rate constant from the fulllength RNA; $\left(k_{\text {Deg1 }}\right)$ degradation rate constant of the full-length RNA; $\left(k_{\text {Deg2 } 2}\right)$ degradation rate constant of cleaved RNA; $(\phi)$ RNA degradation. Leaky translation from ligand-bound full-length RNA (FL) was not shown in this scheme for simplicity, but this process was included in the equation (see Eq. 4 in the Supplemental Material). (C) Schematic representation of translation routes. In this model, there are three routes of protein translation: one route for ligand-dependent translation and two routes for ligand-independent translation. The ligand-dependent route is the major route of translation in the presence of ligand, depending on translation from the cleaved RNA produced by ligand-dependent self-cleavage. Ligand-independent route 1 is translation from the cleaved RNA produced by a ligandindependent process. Ligand-independent route 2 is leaky translation from the full-length RNA. 
the background translation route from noncleaved RNA and assumed a single state for the noncleaved RNA because they are kinetically equivalent (for details, see the Supplemental Material). In this model, the full-length RNA (F) is transcribed from DNA (DNA) encoding an aptazyme and a protein with the first-order rate constant $k_{\mathrm{Txn}}$. In the presence of ligand $(\mathrm{L})$, the full-length RNA binds to the ligand to form the complex (FL) with the second-order rate constant $k_{\mathrm{on}}$. The complex dissociates with the first-order rate constant $k_{\text {off. }}$ The complex cleaves itself by the ribozyme activity to form the cleaved RNA (C) with the firstorder constant $k_{\text {Cle1 }}$. From the cleaved RNA, the protein (Protein) is translated with the first-order constant $k_{\text {Prol }}$. Here, we assigned a first-order rate constant for translation because the cell-free translation system used here contains abundant ribosomes $(3 \mu \mathrm{M}$ total and $\sim 510 \mathrm{nM}$ active ribosomes) (Ichihashi et al. 2008). We designated this ligand-dependent translation as the Ligand-dependent route (Fig. 2C). Translation of the protein, however, can occur even in the absence of ligand as has been reported previously (Ogawa and Maeda 2007; Wieland et al. 2009). We introduced two possible routes for such ligand-independent translation into this model. The first route involves translation from the cleaved RNA produced by ligand-independent self-cleavage, known to occur depending on the experimental conditions (Wieland and Hartig 2008). Here, we designated this ligand-independent selfcleavage rate constant as $k_{\mathrm{Cle} 2}$ and this translation route as Ligand-independent route 1 . The second route is leaky translation from the full-length RNA. Although the fulllength RNA is designed to mask its SD sequence by hybridization with the antisense region in the absence of ligand, translation can proceed at a slow rate due to stochastic fluctuation of hybridization. We designated this leaky translation rate constant from the full-length RNA (F and $\mathrm{FL})$ as $k_{\mathrm{Pro} 2}$, and this cleavage-independent translation route as Ligand-independent route 2 . In addition, this model contains RNA degradation processes for all RNA species (F, FL, and $\mathrm{C}$ ) with the first-order rate constant. Because selfcleavage of RNA can change the degradation rate depending on the genetic background (Carothers et al. 2011), we assigned two different degradation rate constants, $k_{\mathrm{Deg} 1}$ and $k_{\text {Deg2 }}$, for the full-length and cleaved RNA, respectively. DNA and protein degradation are neglected because of their slow rates compared with RNA degradation.

\section{Parameter estimation}

According to the model, the function of an aptazyme is determined by nine parameters: $k_{\mathrm{Txn}}, k_{\mathrm{on}}, k_{\mathrm{off}}, k_{\mathrm{Deg} 1}, k_{\mathrm{Deg} 2}$, $k_{\mathrm{Cle} 1}, k_{\mathrm{Cle} 2}, k_{\mathrm{Pro} 1}$, and $k_{\mathrm{Pro} 2}$. We next attempted to estimate these parameters by curve fitting with the kinetic data obtained in switching experiments by an aptazyme in a cellfree translation system. We used a DNA encoding an onswitching aptazyme (Clone 1.2), which was developed by
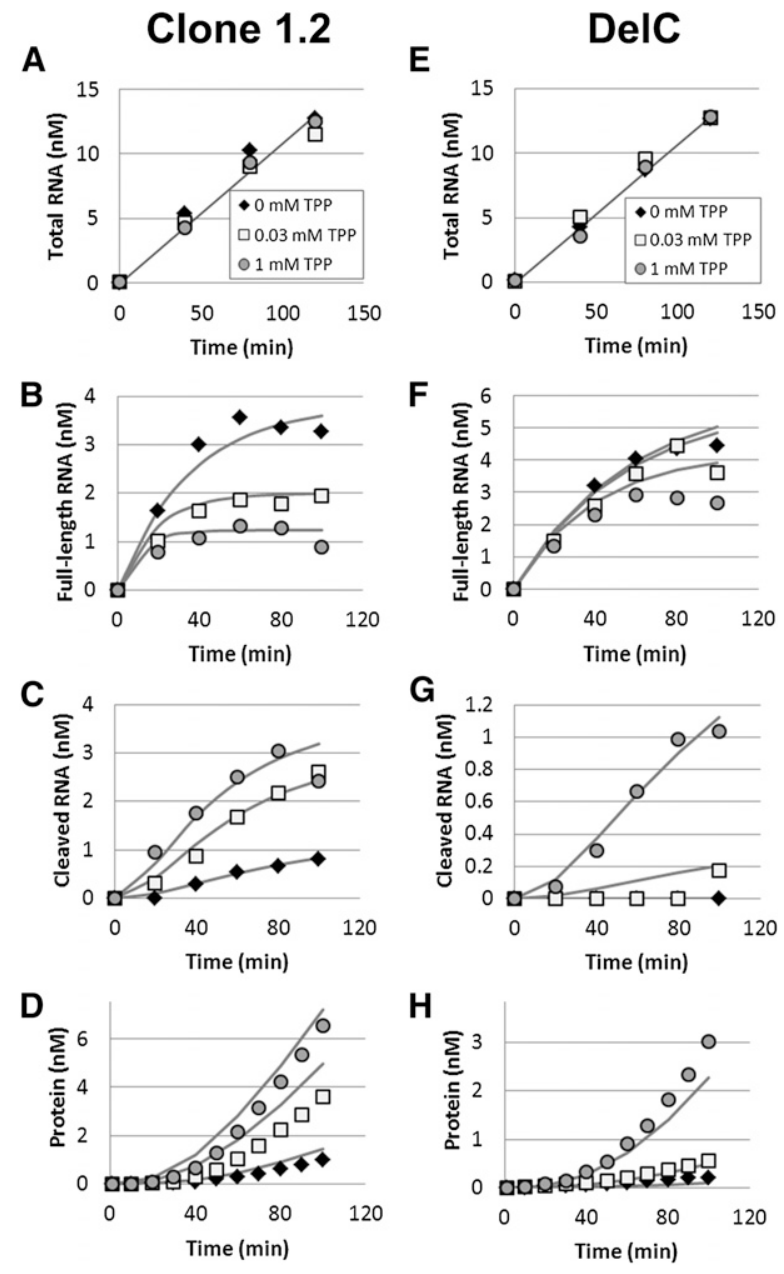

FIGURE 2. Kinetics of the RNAs and the protein in the switching of gene expression by the aptazymes. (Left and right columns) The results for Clone $1.2(A-D)$ and DelC mutant $(E-H)$, respectively. DNA (3 $\mathrm{nM}$ ) encoding the aptazyme and GFP was incubated in the reconstituted translation system in the presence of $0 \mathrm{mM}$ (black diamonds), $0.03 \mathrm{mM}$ (white squares), or $1 \mathrm{mM}$ (gray circles) TPP. At the indicated times, the total RNA levels including degraded RNA $(A, E)$, full-length RNA $(B, F)$, cleaved RNA $(C, G)$, and protein $(D, H)$ were measured as described in Materials and Methods. We also performed experiments with $0.1 \mathrm{mM}$ and $0.3 \mathrm{mM}$ TPP, but the data used for parameter estimation in Supplemental Figure S1 are not shown here. The results of simulation using the parameters shown in Table 1 and the kinetic model in Figure 1B are shown as lines.

Wieland et al. (2009) to respond to thiamine pyrophosphate (TPP) and the GFP gene downstream. The DNA (3 $\mathrm{nM}$ ) was incubated in a reconstituted translation system of Escherichia coli (Shimizu et al. 2001) with various concentrations of TPP $(0,0.03,0.1,0.3,1 \mathrm{mM})$. At the indicated times, we measured the concentrations of RNA and protein species: total RNA, full-length RNA, cleaved RNA, and GFP protein (dots in Fig. 2A-D; only the data at 0, 0.03, and 1 $\mathrm{mM}$ TPP are shown). The total RNA contained all RNA produced in this experiment including the degraded RNA. The total RNA increased linearly at almost the same rate for all TPP concentrations (Fig. 2A), indicating a constant 
transcription rate until $120 \mathrm{~min}$ irrespective of TPP concentration. The full-length RNA increased until $40 \mathrm{~min}$ and became constant, the level of which decreased with higher TPP concentration (Fig. 2B). The level of cleaved RNA increased gradually until $100 \mathrm{~min}$, the rate of which increased with higher TPP concentration (Fig. 2C). The protein concentration increased in concave curves, the rate of which increased with higher TPP concentration (Fig. 2D). We estimated the parameters by fitting these data with the equations derived from the model as described in Materials and Methods (Table 1; see the Supplemental Material for derivation of the equations). Simulation using these parameters explains the experimental data of 40-100 min within $70 \%$ error (Fig. 2A-D, lines), indicating that the kinetic model quantitatively described the dynamics of gene regulation by the aptazyme in the cell-free translation system.

\section{Dynamics of $\mathrm{S} / \mathrm{N}$ ratio}

We investigated which parameter(s) determines the value and dynamics of the $\mathrm{S} / \mathrm{N}$ ratio. Here, we experimentally defined the $\mathrm{S} / \mathrm{N}$ ratio as the protein concentration in the presence of $1 \mathrm{mM}$ TPP (signal) divided by that in the absence of TPP (noise). The experimental S/N ratio decreased slightly from 40 to $100 \mathrm{~min}$ (Fig. 3A, dots). The simulation using the model and the parameters showed a similar trend (Fig. 3A, line), supporting the validity of analyzing the $\mathrm{S} / \mathrm{N}$ ratio using this model. Next, we analyzed translation routes for signal and noise production by simulation. Signal was mainly produced through liganddependent RNA cleavage (i.e., the Ligand-dependent route in Fig. 1C). This result was not surprising because the aptazyme was originally designed to optimize this liganddependent translation route. In contrast, noise can be produced through two different routes; translation from the ligand-independently cleaved RNA (the Ligand-indepen-

TABLE 1. Parameters of aptazymes

\begin{tabular}{lcc}
\hline & Clone 1.2 & DelC \\
\hline$k_{\text {Txn }}$ & $0.036 \pm 0.002$ & $0.035 \pm 0.001 / \mathrm{min}$ \\
$k_{\text {Cle1 }}$ & $0.069 \pm 0.005$ & $0.009 \pm 0.001 / \mathrm{min}$ \\
$K_{\mathrm{d}}{ }^{a}$ & $0.042 \pm 0.012$ & $0.20 \pm 0.08 \mathrm{mM}$ \\
$k_{\text {Deg1 }}$ & $0.022 \pm 0.002$ & $0.023 \pm 0.001 / \mathrm{min}$ \\
$k_{\text {Deg2 }}$ & $0.023 \pm 0.002$ & $0.015 \pm 0.004 / \mathrm{min}$ \\
$k_{\text {Cle2 }}$ & $0.0065 \pm 0.005$ & $<0.0001 / \mathrm{min}$ \\
$k_{\text {Pro1 }}$ & $0.037 \pm 0.002$ & $0.043 \pm 0.003 / \mathrm{min}$ \\
$k_{\text {Pro2 }}$ & $\mathrm{ND}^{\mathrm{b}}$ & $0.00025 \pm 0.00016 / \mathrm{min}$ \\
\hline
\end{tabular}

${ }^{\mathrm{a} D i s s o c i a t i o n}$ and association between ligand and full-length RNA were assumed to be in equilibrium at the dissociation constant $K_{\mathrm{d}}$ $\left(=k_{\text {off }} / k_{\text {on }}\right)$.

${ }^{\mathrm{b}} k_{\text {Pro2 }}$ of Clone 1.2 was not determined due to excessive translation from the ligand-dependent route. For the simulation in Figure 3B,C, we assumed that the value was the same as DelC.
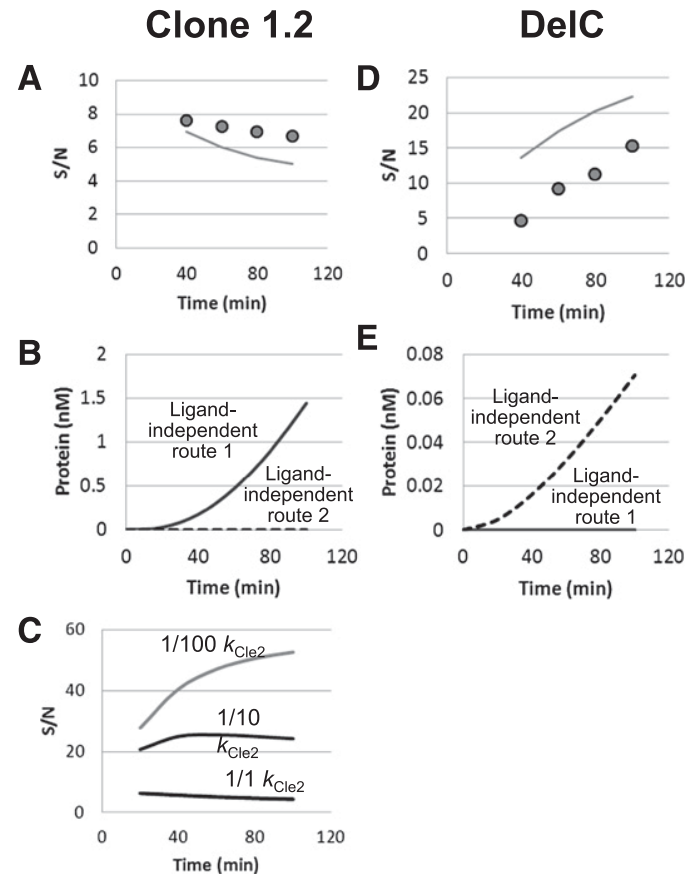

FIGURE 3. Analysis of the $\mathrm{S} / \mathrm{N}$ ratio. (Left and right columns) The results for Clone $1.2(A-C)$ and DelC mutant $(D, E)$, respectively. $(A, D) \mathrm{S} / \mathrm{N}$ ratios. The experimental $\mathrm{S} / \mathrm{N}$ ratios were determined by division of the protein concentration with $1 \mathrm{mM}$ TPP by that with $0 \mathrm{mM}$ TPP in Figure 2D,H (circles). The simulation results of the $\mathrm{S} / \mathrm{N}$ ratio were obtained using the model shown in Figure $1 \mathrm{~B}$ and the parameters in Table 1 (lines). ( $B, E)$ Contributions of the two ligandindependent routes in Figure $1 \mathrm{C}$ for translation in the absence of TPP (Noise). Contributions of ligand-independent route 1 (solid lines) and ligand-independent route 2 (broken lines) were analyzed by simulation using the model and the parameters. (C) Simulation of $\mathrm{S} / \mathrm{N}$ dynamics with decreased $k_{\mathrm{Cle} 2}$. Transition of the dynamics of the $\mathrm{S} / \mathrm{N}$ ratio of Clone 1.2 was simulated by decreasing $k_{\mathrm{Cle} 2}$, keeping the other parameters unchanged. Note that in this simulation, we assumed that the $k_{\mathrm{Pro} 2}$ value of Clone 1.2 was the same as that of the DelC mutant $(0.0034 / \mathrm{min})$, because the value of Clone 1.2 was not determined.

dent route 1 in Fig. 1C) and leaky translation from the fulllength RNA (Ligand-independent route 2). Analysis of the contributions of each route showed that the noise of this Clone 1.2 aptazyme was mainly derived from Ligandindependent route 1 (Fig. 3B), consistent with the experimental observation that a small amount of cleaved RNA was observed even at $0 \mathrm{mM}$ TPP (Fig. 2C). This result suggested that one of the factors determining the $\mathrm{S} / \mathrm{N}$ ratio of Clone 1.2 under these experimental conditions is the ligandindependent cleavage rate $k_{\mathrm{Cle} 2}$.

To test this suggestion, we first investigated whether the $\mathrm{S} / \mathrm{N}$ ratio increased when $k_{\mathrm{Cle} 2}$ decreased by simulation. We performed a simulation with decreased $k_{\mathrm{Cle} 2}$ to $1 / 10$ and $1 / 100$, keeping the other parameters unchanged, and found that the absolute value of the $\mathrm{S} / \mathrm{N}$ ratio increased (Fig. $3 \mathrm{C}$ ), consistent with the prediction. Interestingly, the dynamics of the $\mathrm{S} / \mathrm{N}$ ratio also changed; the $\mathrm{S} / \mathrm{N}$ ratio was almost constant from 40 to $100 \mathrm{~min}$ at the original values of $k_{\mathrm{Cle} 2}$ 
(denoted as $1 / 1 k_{\mathrm{Cle} 2}$ in Fig. 3C), but increased gradually at $k_{\mathrm{Cle} 2}$ of $1 / 100$. This shift in $\mathrm{S} / \mathrm{N}$ ratio dynamics could be explained as follows. At a large $k_{\mathrm{Cle} 2}$ value, noise is produced from the cleaved RNA produced ligand-independently (Ligand-independent route 1). In this case, as both the signal and the noise are produced from the same type of molecule (i.e., the cleaved RNA), their time dependencies are the same, resulting in a constant $\mathrm{S} / \mathrm{N}$ ratio. On the other hand, at a smaller $k_{\mathrm{Cle} 2}$ value, noise is produced through leaky translation from the full-length RNA (Noise route 2). In this case, the signal and the noise are produced from different types of molecule, the cleaved RNA and the fulllength RNA, respectively, which have different time dependencies as shown in Figure 2B,C; the full-length RNA reached a constant level after $40 \mathrm{~min}$, while the cleaved RNA increased until $100 \mathrm{~min}$. Therefore, the $\mathrm{S} / \mathrm{N}$ ratio increased until $100 \mathrm{~min}$ in this case. This simulation result allowed us to test the predictability of the model; if the ligand-independent cleavage rate $\left(k_{\mathrm{Cle} 2}\right)$ is decreased sufficiently, the dynamics of the $\mathrm{S} / \mathrm{N}$ ratio should change as well as the absolute value.

\section{Analysis of a mutant with smaller $\boldsymbol{k}_{\mathrm{Cle} 2}$}

To test the prediction experimentally, we examined the dynamics of the $\mathrm{S} / \mathrm{N}$ ratio of an aptazyme mutant with smaller $k_{\mathrm{Cle} 2}$. We used a mutant lacking the $\mathrm{C}$ at position 17 of Clone 1.2, designated as DelC (Fig. 1A). This mutant was found in our laboratory by screening of aptazymes that produce lower levels of GFP fluorescence in the absence of ligand. The deletion site resides in Stem I, an important structure for the self-cleavage activity of the hammerhead ribozyme (Yen et al. 2004). We measured the kinetics of the RNAs and the protein (Fig. 2E-H, dots) and estimated the parameters in the same way as for Clone 1.2 (Table 1). The $k_{\mathrm{Cle} 2}$ of this mutant was much smaller than that of Clone $1.2(<1 / 65)$, and the $k_{\mathrm{Cle} 1}$ also decreased to $1 / 8$, while $K_{\mathrm{d}}$ increased by about fivefold, indicating that both the ribozyme activity and the affinity for the ligand of this mutant were lower than those of Clone 1.2. Other parameters $-k_{\mathrm{Txn}}, k_{\mathrm{Deg} 1}, k_{\mathrm{Deg} 2}$, and $k_{\mathrm{Pro} 1}$-were similar to that of Clone 1.2, which was reasonable because these parameters are not directly related to the deletion site. The simulation using these parameters explained the experimental data (40-100 $\mathrm{min}$ ) within 70\% error (Fig. 2E-H, lines).

The experimental $\mathrm{S} / \mathrm{N}$ ratio of this mutant increased over time (Fig. 3D, dots). The trend was consistent with the simulation using the model and the parameters (Fig. 3D, line). Analysis of the translation routes showed that the signal was mainly produced through ligand-dependent RNA cleavage (i.e., the Ligand-dependent route in Fig. 1C), similar to Clone 1.2. In contrast, the production route for the noise of the DelC mutant mainly involved leaky translation from the full-length RNA (Ligand-independent route 2), which was negligible for Clone 1.2 (Fig. 3E). This result suggested that the decrease in the ligand-independent self-cleavage rate $k_{\mathrm{Cle} 2}$ of this mutant shifted the main cause of the noise from Ligand-independent route 1 to Ligandindependent route 2 , and consequently changed the $\mathrm{S} / \mathrm{N}$ ratio dynamics from constant to increasing. This consistency of experimental data and the prediction by the simulation strongly support the validity of using this model for analysis of the aptazyme $\mathrm{S} / \mathrm{N}$ ratio.

To test the predictive capability of this model further, we attempted to improve the $\mathrm{S} / \mathrm{N}$ ratio. According to the model, given that the main noise route of DelC is leaky translation, mutations that strengthen the stem region containing the SD sequence should decrease the noise expression, resulting in an increase in the $\mathrm{S} / \mathrm{N}$ ratio. To test this suggestion, we introduced three types of mutation that lengthen the stem containing the SD sequence (Supplemental Fig. S3a). Introduction of all of the three mutations into Clone 1.2 did not increase the $\mathrm{S} / \mathrm{N}$ ratio, whereas the introduction of two of the mutations into DelC enhanced he $\mathrm{S} / \mathrm{N}$ ratio by twofold to fourfold. This result confirmed the validity of our model and also suggested the usefulness of the model for design strategies to improve aptazymes.

We further applied this model to another type of aptazyme developed by Ogawa and coworkers that responds to theophylline. The $g f p$ gene was attached downstream from the aptazyme, and GFP fluorescence was measured in the presence $(2 \mathrm{mM})$ or absence of theophylline. The $\mathrm{S} / \mathrm{N}$ ratio of this aptazyme increased over time (Supplemental Fig. $\mathrm{S} 4 \mathrm{a}$ ). This trend was the same as that of the DelC mutant, implying that the main noise route of this theophylline aptazyme is leaky translation. If this is, indeed, the case, the level of cleaved RNA in the absence of theophylline would be low for this aptazyme. To test this suggestion, we measured the levels of full-length and cleaved RNA in the presence or absence of theophylline; the cleaved RNA was undetectable in the absence of theophylline (Supplemental Fig. S4c), similar to DelC mutant (see Fig. 2G), indicating that our model is also applicable to this aptazyme.

\section{DISCUSSION}

In this study, we first constructed a kinetic model based on that reported previously (Chen and Ellington 2009). The model assumes a single route for ligand-dependent gene expression (signal) and two different routes for ligandindependent gene expression (noise). The simulation using the model quantitatively described the dynamics of individual components as well as the $\mathrm{S} / \mathrm{N}$ ratio in aptazymeregulated gene expression. Moreover, the analysis of two aptazymes with different rate constants demonstrated that the dynamics of the $\mathrm{S} / \mathrm{N}$ ratio changed significantly depending on the main noise route.

In addition to the dynamics of the $\mathrm{S} / \mathrm{N}$ ratio, the difference in the main noise route determined the level of the $\mathrm{S} / \mathrm{N}$ ratio 
at steady state as follows (for derivation, see the Supplemental Material).

In the case that the noise is produced by ligandindependent cleavage (Ligand-independent route 1), the $\mathrm{S} / \mathrm{N}$ ratio at steady state is shown as

$$
\frac{\mathrm{S}}{\mathrm{N}}^{\text {route }-1}=\frac{\left(k_{\mathrm{Cle} 1}+k_{\mathrm{Deg} 1}-k_{\mathrm{Deg} 2}\right)\left(k_{\mathrm{Cle} 2}+k_{\mathrm{Deg} 1}\right)}{\left(k_{\mathrm{Cle} 2}+k_{\mathrm{Deg} 1}-k_{\mathrm{Deg} 2}\right)\left(k_{\mathrm{Cle} 1}+k_{\mathrm{Deg} 1}\right)}
$$

where the $\mathrm{S} / \mathrm{N}$ ratio depends on four parameters: $k_{\mathrm{Cle} 1}$, $k_{\mathrm{Cle} 2}, k_{\mathrm{Deg} 1}$, and $k_{\mathrm{Deg} 2}$. This result indicated that the effective method to improve the $\mathrm{S} / \mathrm{N}$ ratio in this case differs depending on the relative magnitudes of these four parameters. For example, in the case of the similar degradation rate for both the full-length and cleaved RNA (i.e., $k_{\text {Deg1 }}=$ $\left.k_{\text {Deg2 }}\right)$, the effective method to improve the $\mathrm{S} / \mathrm{N}$ ratio is to change the ligand dependency of ribozyme activity, e.g., by modification of the sequence in the junction between the aptamer and regulator domains.

On the other hand, in the case in which the noise is produced by leaky translation from the full-length RNA (Ligand-independent route 2) and under conditions of much larger degradation rate than cleavage rate (i.e., $k_{\text {Deg1 }} \gg$ $\left.k_{\mathrm{Cle} 1}, k_{\mathrm{Cle} 2}\right)$, the $\mathrm{S} / \mathrm{N}$ ratio at steady state is shown as

$$
\frac{\mathrm{S}}{\mathrm{N}}^{\text {route-2}}=\frac{k_{\mathrm{Pro1}} k_{\mathrm{Cle} 1}\left(k_{\mathrm{Cle} 2}+k_{\mathrm{Deg} 1}\right)}{k_{\mathrm{Pro} 2} k_{\mathrm{Deg} 2}\left(k_{\mathrm{Cle} 1}+k_{\mathrm{Deg} 1}\right)}
$$

where the $\mathrm{S} / \mathrm{N}$ ratio depends on six parameters: $k_{\mathrm{Cle} 1}, k_{\mathrm{Cle} 2}$, $k_{\mathrm{Deg} 1}, k_{\mathrm{Deg} 2}, k_{\mathrm{Pro} 1}$, and $k_{\mathrm{Pro} 2}$. This result indicates that there are several strategies to improve aptazymes in this case, such as the introduction of mutations that strengthen hybridization of the SD sequence to decrease leaky translation, modification of the sequence involved in ribozyme activity to enhance the activity, or reduction of the RNA degradation rate. The reduction of RNA degradation would be possible by chemical modification of RNA or by simply adding RNase inhibitors in vitro, or by using strains harboring mutations to increase RNA stability in vivo (Leeds et al. 1992).

This knowledge regarding the determinants of the $\mathrm{S} / \mathrm{N}$ ratio would be useful to improve aptazymes more efficiently. To date, attempts to improve aptazymes have largely relied on screening from random mutation libraries (Koizumi et al. 1999; Wieland and Hartig 2008; Wieland et al. 2009). The searchable sequence space, however, is always much smaller than the possible sequence space, even using high-throughput screening systems. One of the most efficient ways to increase screening efficiency is to narrow down the randomized region using knowledge regarding the limiting factors of the current aptazyme. For example, if the limiting factor of the $\mathrm{S} / \mathrm{N}$ ratio is leaky translation, it would be more efficient to focus on mutant libraries with mutations around the SD sequence and its antisense region, as we demonstrate in Supplemental Figure S3. Therefore, knowledge regarding the determinants of the $\mathrm{S} / \mathrm{N}$ ratio would be useful to narrow down the possible mutational region and thus enhance screening efficiency. Note that this model is only valid for aptazymes that release the ribosomal binding site in bacteria. Another model is needed to analyze aptazymes that alter mRNA stability upon ligand binding (Carothers et al. 2011).

In summary, parameters that determine the $\mathrm{S} / \mathrm{N}$ ratio of gene regulation by on-switch aptazymes would vary depending on the origin of translation in the absence of ligand (noise), either ligand-independent cleavage or leaky translation from full-length RNA. This raises a question regarding how the origin can be determined. Here, we proposed a simple method for this purpose involving examination of the $\mathrm{S} / \mathrm{N}$ ratio dynamics. If the $\mathrm{S} / \mathrm{N}$ ratio becomes constant before the cleaved RNA reaches a steady state:

$$
\left(\left(k_{\mathrm{Cle} 1}+k_{\mathrm{Cle} 2}+k_{\mathrm{Deg} 1}\right) k_{\mathrm{Deg} 2}\right)^{-\frac{1}{2}}
$$

(for derivation, see the Supplemental Material), the noise of the aptazyme would be mainly produced by ligand-independent cleavage. If the $\mathrm{S} / \mathrm{N}$ ratio increases until this time, the noise of the aptazyme would be mainly produced by leaky translation from the full-length RNA. Although this concept was obtained in an in vitro system, it would also be applicable to in vivo systems if the $\mathrm{S} / \mathrm{N}$ ratio can be measured after induction of aptazyme transcription. The observation of $\mathrm{S} / \mathrm{N}$ dynamics would provide an easy method to assess restriction factors for aptazyme switching ability.

This study was performed in vitro, where many conditions are different from those in vivo. First, in this study, the maximum responses of the aptazymes were obtained with $0.3 \mathrm{mM}$ TPP (Supplemental Fig. S1b), which is much lower than that in vivo ( $>1 \mathrm{mM}$ ) (Wieland et al. 2009). This difference may be due to the lack of membrane transport and metabolism of TPP in the in vitro system. Second, here we used T3 polymerase for transcription instead of $E$. coli polymerase and a higher magnesium concentration (11.55 $\mathrm{mM}$ ) than that in vivo. These differences may result in differences in folding of aptazymes (Lewicki et al. 1993; Chao et al. 1995). Third, many factors that may affect the aptazyme functions in vivo are not included in the in vitro system, such as RNA and protein degradation by several types of RNases and proteinases. Because of these differences, Clone 1.2, originally optimized for in vivo application (Wieland and Hartig 2008), may show a higher ligandindependent self-cleavage rate in this study. Parameters obtained in the in vitro system may not be directly applicable to in vivo systems. However, the simplicity and controllability of the in vitro system make it useful to examine the basic effects of various factors, such as transcription, ribozyme activity, RNA degradation, and protein degradation, on aptazyme function.

Recently, riboswitches and other nucleotide-based regulators have been used for broader applications not only for the regulation of gene expression in vivo, but also for in 
vitro applications, such as biosensors (Breaker 2002; Hesselberth et al. 2003; Ogawa and Maeda 2007), nucleotide-based machinery for information processing (Stojanovic and Stefanovic 2003; Benenson et al. 2004), and environment-responsive artificial cell models (Martini and Mansy 2011). The simplicity and design potential of aptazymes, combined with cell-free translation systems, enable the development of controllable artificial systems responsive to various signal compounds. The design and construction of controllable systems require a precise understanding of the dynamics of the reactions involved. The kinetic model in this study provided a quantitative framework for the construction of various types of in vitro systems implemented with aptazyme-regulated gene expression.

\section{MATERIALS AND METHODS}

\section{Materials}

To construct a plasmid harboring the GFP gene downstream from aptazyme Clone 1.2 (Wieland et al. 2009), we introduced a synthesized aptazyme sequence with a T3 promoter just before the $g f p$ gene of pETG5tag (Sunami et al. 2006), yielding pETg5-T3-TPP1. The DNA used in the experiments was prepared by PCR using primers atcggtgatgtcggcgatatag and gctagttattgctcagcgg, and the plasmid pETg5-T3-TPP1 as a template. A reconstituted translation system of E. coli (PURE System) (Shimizu et al. 2001) was used, although the composition of the components was modified originally; the protein composition was the same as described previously (Hosoda et al. 2008) except using T3 RNA polymerase (0.0652 unit/20 $\mu \mathrm{L}, 17$ units/ $\mu \mathrm{L}$; Promega) instead of T7 RNA polymerase. The composition of low-molecular-weight compounds was as follows: $0.3 \mathrm{mM}$ of 20 amino acids, $0.4 \mu \mathrm{g} / \mu \mathrm{L}$ tRNA mix (Roche), 2 mM ATP, 2 mM GTP, 1 mM CTP, 1 mM UTP, 50 mM HEPES$\mathrm{KOH}$ ( $\mathrm{pH} 7.6$ ), $50 \mathrm{mM}$ glutamate potassium, $2 \mathrm{mM}$ spermidine, $11.55 \mathrm{mM}$ magnesium acetate, $20 \mathrm{mM}$ creatine phosphate, $1 \mathrm{mM}$ dithiothreitol, and $10 \mathrm{ng} / \mu \mathrm{L}$ 10-formyl-5,6,7,8-tetrahydrofolic acid.

\section{Kinetic model}

Based on the scheme shown in Figure 1B, the differential equations of each component, the full-length RNA, cleaved RNA, and protein were derived and solved analytically. The analytical solutions were used for simulations (for details, see the Supplemental Material).

\section{Parameter estimation}

Briefly, the parameters of the aptazymes $-k_{\mathrm{Txn}}, K_{d}, k_{\mathrm{Deg} 1}, k_{\mathrm{Deg} 2}$, $k_{\mathrm{Cle} 1}, k_{\mathrm{Cle} 2}, k_{\mathrm{Pro} 1}$, and $k_{\mathrm{Pro} 2}$-were estimated by curve fitting of the data of RNA and protein kinetics with the various TPP concentrations partially shown in Figure 2 with Equations 13, 15, 16, and 17 (Supplemental Material) with the Levenberg-Marquardt algorithm using the Origin computer program (OriginLab). The procedures are described in detail below.

\section{Estimation of $\mathrm{k}_{T x n}$}

The value of $k_{\text {Txn }}$ was estimated by linear regression of the kinetics of the total RNA concentration (Fig. 2A,E) with Equation 16, given the constant DNA concentration, $[\mathrm{DNA}]=3 \mathrm{nM}$.
Estimation of $\mathrm{k}_{\text {Deg1 }}, \mathrm{k}_{\text {Deg2 }}, \mathrm{k}_{C l e 1}, \mathrm{k}_{C l e 2}$, and $\mathrm{K}_{d}$

First, we estimated the values of $\alpha\left(=k_{\mathrm{Cle} 2}+k_{\mathrm{Deg} 1}+\frac{k_{\mathrm{Cle} 1}\left[\mathrm{~L}_{\mathrm{Total}}\right]}{K_{d}+\left[\mathrm{L}_{\mathrm{Total}}\right)}\right)$, $k_{\mathrm{Deg} 2}$, and $k_{\mathrm{Deg} 2}$ by curve fitting of the kinetic data of the fulllength RNA and the cleaved RNA with Equations 13 and 15, respectively (Supplemental Fig. S1a,b,e,f). In this fitting, $\alpha$ was treated as an independent variable for each ligand concentration, and $k_{\mathrm{Deg} 1}$ and $k_{\mathrm{Deg} 2}$ were treated as common variables for all ligand concentrations. Here, we also used the data with 0.1 and 0.3 $\mathrm{mM}$ TPP, not shown in Figure 2. Second, we estimated $k_{\text {Deg1 }}+$ $k_{\mathrm{Cle} 2}, k_{\mathrm{Cle} 1}$, and $K_{\mathrm{d}}$ by plotting the values of $\alpha$ as a function of the total ligand concentration $\left(\left[\mathrm{L}_{\text {Total }}\right]\right)$ and fitting the plot with Equation 14 (Supplemental Fig. S1c,g). Third, we estimated the value of $k_{\mathrm{Cle} 2}$ by subtracting $k_{\mathrm{Deg} 1}$ from $k_{\mathrm{Deg} 1}+k_{\mathrm{Cle} 2}$.

\section{Estimation of $\mathrm{k}_{\text {Pro } 1}$ and $\mathrm{k}_{\text {Pro2 }}$}

These parameters were estimated from the kinetics of GFP protein with various TPP concentrations. The GFP fluorescence was measured every $1 \mathrm{~min}$ until $100 \mathrm{~min}$ and converted to absolute concentration as described below. Parts of the data are shown in Figure 2, D and H. From the kinetics of GFP protein concentration, we obtained the rate of protein synthesis every $10 \mathrm{~min}$ for 0-0.1 mM TPP. According to Equation 17, we plotted

$$
\frac{d[\text { Protein }]}{d t} /[\mathrm{C}] \text { versus }\left[\mathrm{F}_{\text {Total }}\right] /[\mathrm{C}]
$$

and performed linear regression to estimate $k_{\mathrm{Pro} 1}$ and $k_{\mathrm{Pro} 2}$ as common variables for all TPP concentrations (Supplemental Fig. $\mathrm{S} 1 \mathrm{c}, \mathrm{f})$. The values of $[\mathrm{C}]$ and $\left[\mathrm{F}_{\text {Total }}\right]$ were obtained from the simulation using Equations 13 and 15 and the parameters estimated above.

\section{Measurement of RNA and protein concentrations}

RNA was measured by radioisotope incorporation. Briefly, we added $\left[{ }^{32} \mathrm{P}\right] \mathrm{UTP}$ to the reconstituted translation system followed by incubation with the DNA at $37^{\circ} \mathrm{C}$. At the indicated times, aliquots were purified with an RNeasy column (QIAGEN) and subjected to $4 \%$ polyacrylamide gel electrophoresis containing $7 \mathrm{M}$ urea in TBE buffer, followed by autoradiography. For fulllength and cleaved RNA, we quantified the intensities of the corresponding bands. For total RNA, including degraded RNA, we quantified all of the bands larger than 100 bases, which included the full-length and cleaved RNAs, and their degradation products smearing downward, but did not include unreacted methionine. The protein concentrations used for parameter estimation were calculated from GFP fluorescence measured with a fluorometer $(\mathrm{Mx} 3005 \mathrm{P}$; Agilent) using a convergence factor ([Protein] $=$ Fluorescence/165) estimated by comparison between GFP fluorescence and protein concentration measured by radioisotope incorporation assay under the same conditions (Supplemental Fig. S2). The radioisotope incorporation assay for protein concentration was performed by incubation of the DNA with the cell-free translation system with $\left[{ }^{35} \mathrm{~S}\right]$-methionine, and GFP protein was separated by $10 \%$ SDS-PAGE, followed by autoradiography. To determine the absolute protein concentration, the cell-free translation system was spotted with $\left[{ }^{35} \mathrm{~S}\right]$-methionine on paper, with a known methionine concentration, and the radioactivity was compared with that of the GFP band. 


\section{SUPPLEMENTAL MATERIAL}

Supplemental material is available for this article.

\section{ACKNOWLEDGMENTS}

We are grateful to Naoko Miki, Hitomi Komai, and Ryoko Otsuki for their technical assistance. This research was supported in part by the Global COE (Centers of Excellence) Program of the Ministry of Education, Culture, Sports, Science, and Technology, Japan.

Received February 14, 2012; accepted May 26, 2012.

\section{REFERENCES}

Araki M, Okuno Y, Hara Y, Sugiura Y. 1998. Allosteric regulation of a ribozyme activity through ligand-induced conformational change. Nucleic Acids Res 26: 3379-3384.

Bayer TS, Smolke CD. 2005. Programmable ligand-controlled riboregulators of eukaryotic gene expression. Nat Biotechnol 23: 337-343.

Benenson Y, Gil B, Ben-Dor U, Adar R, Shapiro E. 2004. An autonomous molecular computer for logical control of gene expression. Nature 429: 423-429.

Breaker RR. 2002. Engineered allosteric ribozymes as biosensor components. Curr Opin Biotechnol 13: 31-39.

Carothers JM, Goler JA, Juminaga D, Keasling JD. 2011. Model-driven engineering of RNA devices to quantitatively program gene expression. Science 334: 1716-1719.

Chao MY, Kan MC, Lin-Chao S. 1995. RNAII transcribed by IPTGinduced T7 RNA polymerase is non-functional as a replication primer for ColE1-type plasmids in Escherichia coli. Nucleic Acids Res 23: 1691-1695.

Chen X, Ellington AD. 2009. Design principles for ligand-sensing, conformation-switching ribozymes. PLoS Comput Biol 5: e1000620. doi: 10.1371/journal.pcbi.1000620.

Davidson EA, Ellington AD. 2005. Engineering regulatory RNAs. Trends Biotechnol 23: 109-112.

Desai SK, Gallivan JP. 2004. Genetic screens and selections for small molecules based on a synthetic riboswitch that activates protein translation. J Am Chem Soc 126: 13247-13254.

Hesselberth JR, Robertson MP, Knudsen SM, Ellington AD. 2003. Simultaneous detection of diverse analytes with an aptazyme ligase array. Anal Biochem 312: 106-112.

Hosoda K, Sunami T, Kazuta Y, Matsuura T, Suzuki H, Yomo T. 2008. Quantitative study of the structure of multilamellar giant liposomes as a container of protein synthesis reaction. Langmuir 24: $13540-13548$.

Ichihashi N, Matsuura T, Kita H, Hosoda K, Sunami T, Tsukada K, Yomo T. 2008. Importance of translation-replication balance for efficient replication by the self-encoded replicase. ChemBioChem 9: 3023-3028.

Isaacs FJ, Dwyer DJ, Collins JJ. 2006. RNA synthetic biology. Nat Biotechnol 24: 545-554.

Karzbrun E, Shin J, Bar-Ziv RH, Noireaux V. 2011. Coarse-grained dynamics of protein synthesis in a cell-free system. Phys Rev Lett 106: 048104. doi: 10.1103/PhysRevLett.106.048104.

Koizumi M, Soukup GA, Kerr JN, Breaker RR. 1999. Allosteric selection of ribozymes that respond to the second messengers cGMP and cAMP. Nat Struct Biol 6: 1062-1071.

Kumar D, An CI, Yokobayashi Y. 2009. Conditional RNA interference mediated by allosteric ribozyme. J Am Chem Soc 131: 13906-13907.

Leeds P, Wood JM, Lee BS, Culbertson MR. 1992. Gene products that promote mRNA turnover in Saccharomyces cerevisiae. Mol Cell Biol 12: $2165-2177$.
Lewicki BT, Margus T, Remme J, Nierhaus KH. 1993. Coupling of rRNA transcription and ribosomal assembly in vivo: Formation of active ribosomal subunits in Escherichia coli requires transcription of rRNA genes by host RNA polymerase which cannot be replaced by bacteriophage T7 RNA polymerase. J Mol Biol 231: 581-593.

Lynch SA, Desai SK, Sajja HK, Gallivan JP. 2007. A high-throughput screen for synthetic riboswitches reveals mechanistic insights into their function. Chem Biol 14: 173-184.

Martini L, Mansy SS. 2011. Cell-like systems with riboswitch controlled gene expression. Chem Commun (Camb) 47: 10734-10736.

Ogawa A. 2011. Rational design of artificial riboswitches based on liganddependent modulation of internal ribosome entry in wheat germ extract and their applications as label-free biosensors. RNA 17: 478-488.

Ogawa A, Maeda M. 2007. Aptazyme-based riboswitches as label-free and detector-free sensors for cofactors. Bioorg Med Chem Lett 17: $3156-3160$

Piganeau N, Jenne A, Thuillier V, Famulok M. 2000. An allosteric ribozyme regulated by doxycyline. Angew Chem Int Ed 39: 4369-4373.

Robertson MP, Ellington AD. 1999. In vitro selection of an allosteric ribozyme that transduces analytes to amplicons. Nat Biotechnol 17: $62-66$.

Sharma V, Nomura Y, Yokobayashi Y. 2008. Engineering complex riboswitch regulation by dual genetic selection. J Am Chem Soc 130: $16310-16315$.

Shimizu Y, Inoue A, Tomari Y, Suzuki T, Yokogawa T, Nishikawa K, Ueda T. 2001. Cell-free translation reconstituted with purified components. Nat Biotechnol 19: 751-755.

Soukup GA, Breaker RR. 1999a. Design of allosteric hammerhead ribozymes activated by ligand-induced structure stabilization. Structure 7: 783-791.

Soukup GA, Breaker RR. 1999b. Nucleic acid molecular switches. Trends Biotechnol 17: 469-476.

Soukup GA, Breaker RR. 2000. Allosteric nucleic acid catalysts. Curr Opin Struct Biol 10: 318-325.

Stojanovic MN, Stefanovic D. 2003. A deoxyribozyme-based molecular automaton. Nat Biotechnol 21: 1069-1074.

Suess B, Weigand JE. 2008. Engineered riboswitches: Overview, problems and trends. RNA Biol 5: 24-29.

Suess B, Hanson S, Berens C, Fink B, Schroeder R, Hillen W. 2003. Conditional gene expression by controlling translation with tetracycline-binding aptamers. Nucleic Acids Res 31: 1853-1858.

Suess B, Fink B, Berens C, Stentz R, Hillen W. 2004. A theophylline responsive riboswitch based on helix slipping controls gene expression in vivo. Nucleic Acids Res 32: 1610-1614.

Sunami T, Sato K, Matsuura T, Tsukada K, Urabe I, Yomo T. 2006. Femtoliter compartment in liposomes for in vitro selection of proteins. Anal Biochem 357: 128-136.

Tang J, Breaker RR. 1997. Rational design of allosteric ribozymes. Chem Biol 4: 453-459.

Thompson KM, Syrett HA, Knudsen SM, Ellington AD. 2002. Group I aptazymes as genetic regulatory switches. BMC Biotechnol 2: 21. doi: $10.1186 / 1472-6750-2-21$.

Weigand JE, Sanchez M, Gunnesch EB, Zeiher S, Schroeder R, Suess B. 2008. Screening for engineered neomycin riboswitches that control translation initiation. RNA 14: 89-97.

Wieland M, Hartig JS. 2008. Improved aptazyme design and in vivo screening enable riboswitching in bacteria. Angew Chem Int Ed Engl 47: 2604-2607.

Wieland M, Benz A, Klauser B, Hartig JS. 2009. Artificial ribozyme switches containing natural riboswitch aptamer domains. Angew Chem Int Ed Engl 48: 2715-2718.

Winkler WC, Breaker RR. 2005. Regulation of bacterial gene expression by riboswitches. Annu Rev Microbiol 59: 487-517.

Yen L, Svendsen J, Lee JS, Gray JT, Magnier M, Baba T, D’Amato RJ, Mulligan RC. 2004. Exogenous control of mammalian gene expression through modulation of RNA self-cleavage. Nature 431: 471-476. 

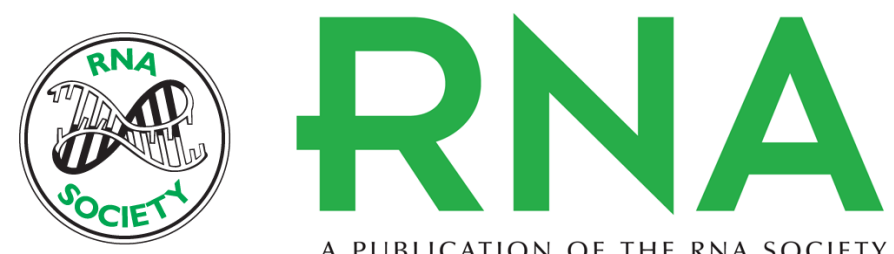

A PUBLICATION OF THE RNA SOCIETY

\section{Kinetic analysis of aptazyme-regulated gene expression in a cell-free translation system: Modeling of ligand-dependent and -independent expression}

Shungo Kobori, Norikazu Ichihashi, Yasuaki Kazuta, et al.

RNA 2012 18: 1458-1465 originally published online June 25, 2012

Access the most recent version at doi:10.1261/rna.032748.112

Supplemental Material

References

License

Email Alerting Service
http://rnajournal.cshlp.org/content/suppl/2012/06/12/rna.032748.112.DC1

This article cites 41 articles, 4 of which can be accessed free at: http://rnajournal.cshlp.org/content/18/8/1458.full.html\#ref-list-1

Receive free email alerts when new articles cite this article - sign up in the box at the top right corner of the article or click here. 